\title{
Protein Turnover in Chlorella fusca var. vacuolata: Measurement of the Overall Rate of Intracellular Protein Degradation using Isotope Exchange with Water
}

\author{
By L. RICHARDS* AND C. F. THURSTON \\ Department of Microbiology, Queen Elizabeth College, Campden Hill Road, \\ London $W 87 A H$
}

(Received 26 October 1979)

\begin{abstract}
Measurements were made of the rate of intracellular protein turnover in Chlorella fusca var. vacuolata, using two methods. Incorporation of ${ }^{18} \mathrm{O}$ into protein from $\mathrm{H}_{2}{ }^{18} \mathrm{O}$-enriched medium occurred at linear rates in both autotrophically growing and nitrogen-starved cells. On the assumption that the only port of ${ }^{18} \mathrm{O}$ incorporation is via the hydrolytic cleavage of peptide bonds followed by resynthesis of the labelled amino acids into new protein, apparent turnover rates were between 1.2 and $2.13 \% \mathrm{~h}^{-1}$ in growing cells, falling to $0.5 \% \mathrm{~h}^{-1}$ at the commencement of starvation. After $17.5 \mathrm{~h}$ starvation, the rate rose again to the growing cell value. However, analysis of the exchanges between the acid and amides of aspartate and glutamate in the free pool showed that ${ }^{18} \mathrm{O}$ can also be incorporated via side-chain exchange, thus causing overestimation of turnover. Labelling of protein by growth in ${ }^{3} \mathrm{H}_{2} \mathrm{O}$ followed by selective measurement of the $\alpha$-carbon tritium has also been used to avoid the problem of isotope reincorporation. However, in growing cells, incorporation continued after washing the cells free of unincorporated tritium. In nitrogen-starved cells, two stability classes were seen, $85 \%$ of protein being degraded at $3.47 \% \mathrm{~h}^{-1}$, and $15 \%$ at $1 \cdot 11 \% \mathrm{~h}^{-1}$. It is suggested that this high rate of turnover results from the exposure of the culture to high levels of radioactivity for long periods, and concluded that neither method alone will yield an absolute value for the rate of protein turnover, but differences between classes of protein with different decay rates will be apparent.
\end{abstract}

\section{INTRODUCTION}

The study of intracellular protein degradation (protein turnover) as a physiological process in micro-organisms has generally been concerned with two distinct but related problems. First, what is the overall rate of protein catabolism within a microbial cell under a particular set of environmental conditions? Secondly, what proportion of total cell protein is capable of being degraded, and what sort of spectrum of individual degradation rates make up the overall rate? Both problems have been extensively studied in bacteria over the last 25 years (Mandelstam, 1960; Goldberg \& Dice, 1974; Goldberg \& St John, 1976) but little attention has been devoted to the study of protein turnover in eukaryotic micro-organisms.

Measurement of the overall rate of protein degradation in bacteria has customarily been performed by using relatively high concentrations of an unlabelled amino acid in the suspending medium to prevent reincorporation of radioactivity when protein prelabelled by the incorporation of radioactive amino acids is degraded (Goldberg \& Dice, 1974). This use of an external trap depends upon rapid and essentially complete exchange between amino acid in the medium and in metabolic pools within the cell. Although such an exchange can occur with vegetative bacterial cells, there is evidence that eukaryotic micro-organisms 
behave differently, so that external trap methods either underestimate protein degradation or do not work at all (Richards \& Thurston, 1980).

The use of alternative procedures which do not depend upon an external trap has not been extensive. Halvorson (1958) employed an elegant internal trap method to demonstrate that the overall rate of turnover in growing Saccharomyces cerevisiae was of the order of $0 \cdot 1 \%$ $\mathrm{h}^{-1}$, but this method depends upon accurate estimation of the relative assimilation of glycine into protein and, via purine biosynthesis, into nucleic acids. It is also dependent upon equilibration between the glycine pools which supply purine biosynthesis and into which glycine is discharged by protein degradation. We are not aware of a way in which this can be established.

Borek et al. (1958) measured the overall rate of protein degradation in Escherichia coli under non-growing conditions by analysis of the incorporation of ${ }^{18} \mathrm{O}$ from $\mathrm{H}_{2}{ }^{18} \mathrm{O}$ into protein, assuming that the incorporation was solely a consequence of ${ }^{18} \mathrm{O}$ incorporation into the carboxyl group of amino acids as a result of the hydrolytic cleavage of peptide bonds. This technique has subsequently been used for the measurement of protein turnover in Bacillus licheniformis during sporulation (Bernlohr, 1972), and in Agrobacterium tumefaciens starved of nitrogen or nitrogen and carbon (Fensom \& Pirt, 1975).

Recently, an alternative isotope exchange technique has been described by Humphrey \& Davies (1975), in which ${ }^{3} \mathrm{H}_{2} \mathrm{O}$ is incorporated into the suspending medium so that amino acids are labelled in the $\alpha$-carbon position during transamination reactions. This is effectively an internal trap method, as after transfer to an unlabelled medium, the transamination processes transfer radioactivity back into water, so that protein degradation may be measured by estimation of the decrease in tritium on the $\alpha$-carbon of amino acid residues in protein. Although their experiments were mostly concerned with Lemna minor and other higher plants, Davies \& Humphrey (1978) measured intracellular protein degradation in the fission yeast Schizosaccharomyces pombe, demonstrating that their exchange technique gives a substantially higher rate than the conventional external trap technique; they attributed the difference to amino acid recycling because exchange of amino acids into the medium was incomplete and/or insufficiently rapid.

In the preceding paper (Richards \& Thurston, 1980), we showed that the unicellular green alga Chlorella fusca var. vacuolata is similar to Saccharomyces cerevisiae, Schizosaccharomyces pombe and, conceivably, most eukaryotic micro-organisms in that amino acids do not readily exchange from intracellular pools into the medium, particularly with growing cells. External trap methods are therefore inappropriate for quantitative measurement of the overall rate of intracellular protein degradation.

In this paper, the methods of Borek et al. (1958) and Humphrey \& Davies (1975) were applied to $C$. fusca in an attempt to determine the extent of intracellular protein degradation in this organism during both growth and nitrogen starvation. The results indicate that neither technique gives values for protein degradation which are solely reliable.

\section{METHODS}

Culture of organism. Chlorella fusca var. vacuolata (Culture Collection of Algae and Protozoa, Cambridge, strain no. 211-8P) was grown autotrophically, maintained under nitrogen starvation and counted as described in the preceding paper (Richards \& Thurston, 1980).

Extraction of protein fractions. Two fractions of cell protein, called 'soluble' and 'insoluble', were extracted from cells of $C$. fusca by a modification of the procedure of Roberts et al. (1955). Cells from 20 to $50 \mathrm{ml}$ culture samples were harvested by centrifugation, washed twice, and resuspended in $10 \mathrm{ml}$ distilled water at $0{ }^{\circ} \mathrm{C}$. The suspension was passed twice through a French press at $135 \mathrm{MPa}$ and $4{ }^{\circ} \mathrm{C}$. By counting chamber measurements, the average cell breakage was $99 \%$ after this treatment. After $1 \mathrm{~h}$ centrifugation at $30000 \mathrm{~g}$ and $4{ }^{\circ} \mathrm{C}$, the supernatant and pellet were treated as follows. To the pellet was added $5 \mathrm{ml} 1 \mathrm{M}-\mathrm{NaOH}$ and mixed vigorously for $15 \mathrm{~min}$. After centrifuging at $2000 \mathrm{~g}$ and $4{ }^{\circ} \mathrm{C}$ for $20 \mathrm{~min}$, the pellet was discarded, and the supernatant (containing the 'insoluble' protein fraction) was neutralized with $\mathrm{HCl}$. This was subsequently treated identically to the original supernatant (containing the 'soluble' protein fraction). 
Each fraction was diluted with trichloroacetic acid (final concentration $5 \%$ ) and allowed to stand at $0{ }^{\circ} \mathrm{C}$ for $1 \mathrm{~h}$ to complete precipitation. Then $10 \mathrm{ml} 75 \%$ ethanol, acidified to $\mathrm{pH} 3.0$ with $\mathrm{HCl}$, was added to the precipitate and the mixture was incubated for $30 \mathrm{~min}$ at $45^{\circ} \mathrm{C}$. Extraction of the precipitate was repeated with fresh acidified ethanol, and then with ether/acidified ethanol $(1: 1, \mathrm{v} / \mathrm{v})$ for $15 \mathrm{~min}$ at $45^{\circ} \mathrm{C}$. This was followed by two extractions with $10 \mathrm{ml} 0.5 \mathrm{M} \cdot \mathrm{H}_{2} \mathrm{SO}_{4}$ at $100{ }^{\circ} \mathrm{C}$. The precipitate was washed with acidified ethanol and ether, dried in a desiccator, and, where appropriate, resuspended in $0 \cdot 1 \mathrm{M}-\mathrm{NaOH}$.

Acid hydrolysis of C. fusca protein. Samples of pure C. fusca protein ( 3 to $5 \mathrm{mg}$ ) and $0.2 \mathrm{ml} 6 \mathrm{M}-\mathrm{HCl}$ were placed in glass ampoules which were then alternately evacuated and flushed with oxygen-free nitrogen three times before sealing. This step limited oxidation of cysteine and methionine during hydrolysis. Ampoules were heated to $105^{\circ} \mathrm{C}$ for $18 \mathrm{~h}$; they were then opened and their contents were evaporated to dryness. The dried samples were resuspended in $2 \mathrm{ml}$ water, and dried again to remove final traces of acid. Residues were dissolved in $1 \mathrm{ml}$ of either water or autoanalyser loading buffer, and centrifuged to remove any insoluble debris.

Amino acid analysis of protein acid hydrolysates. Samples of protein acid hydrolysates $(0.5 \mathrm{ml})$ were separated by a variable programme, four buffer ion-exchange analyser (Locarte, London), separation being carried out on a $40 \mathrm{~cm}$ column of Locarte sulphonated polystyrene resin number 12 . The buffer system

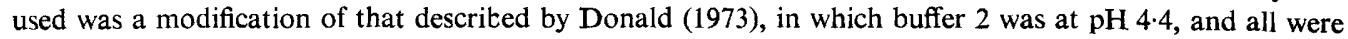
$0.185 \mathrm{M}$ in $\mathrm{Na}^{+}$. Each run consisted of $135 \mathrm{~min}$ of buffer 1 (the first $30 \mathrm{~min}$ at $30^{\circ} \mathrm{C}$, the temperature then rising to $60^{\circ} \mathrm{C}$ for the rest of the separation), followed by $70 \mathrm{~min}$ of buffer $2,60 \mathrm{~min}$ of buffer 3 , and $135 \mathrm{~min}$ of buffer 4 . This selection of buffers and times minimized the interference due to amino sugars in the leucine/phenylalanine region.

The column was regenerated by running for $40 \mathrm{~min}$ with $0 \cdot 2 \mathrm{M}-\mathrm{NaOH}$ followed by $60 \mathrm{~min}$ equilibration in buffer 1. L-Norleucine ( $25 \mathrm{nmol}$ ) was used as an internal standard in all analyses, and for each batch of reagents the analyser was calibrated by running standards consisting of a mixture of $25 \mathrm{nmol}$ of each amino acid being measured except proline, of which $50 \mathrm{nmol}$ was included.

The results were corrected for the degradation of amino acids during hydrolysis, as judged by the degradation observed in standard amino acid mixtures subjected to hydrolysis for different lengths of time and then run on the analyser (Richards, 1978).

The analyser was run in both single and 'split-stream' mode, in which half of the column effluent was reacted with ninhydrin for amino acid quantification, and the other half went to a fraction collector for subsequent estimation of radioactively labelled amino acids. This was done by counting $0.5 \mathrm{ml}$ fractions in $8 \mathrm{ml}$ scintillation fluid [toluene/Triton X-100/2-(4'-tert-butylphenyl)-5-(4"'-biphenylyl)-1,3,4-oxadiazole $(100: 50: 1, \mathrm{v} / \mathrm{v} / \mathrm{w})]$ for $10 \mathrm{~min}$ periods in a scintillation counter at $8{ }^{\circ} \mathrm{C}$. D.p.m. were calculated using the external standard channels ratio method of quench correction.

The reproducibility and linearity of the analyser response to amino acids was very high, a given acid varying in retention time by no more than $2 \%$, and having a linear response to concentration up to $60 \mathrm{nmol}$ with correlation coefficient better than 0.78 for all amino acids.

Estimation of glutamate, glutamine, aspartate and asparagine in C. fusca protein. Acid hydrolysis of protein samples converts the amides of these acids to the free acid, so that separation of the products on the autoanalyser only gives the totals of acid plus amide. These four amino acids were therefore estimated enzymically. The enzymes used were obtained from Sigma.

(i) Aspartate. A two-stage coupled assay was used, modified from that of Pfleiderer (1963), in which aspartate and 2-oxoglutarate were converted by an aminotransferase to glutamate and oxaloacetate, the latter being reduced to malate in the presence of $\beta$-NADH. The reaction was carried out in a $1 \mathrm{~cm}$ path-length silica cuvette, which contained (in a final volume of $1 \mathrm{ml}$ ) $100 \mathrm{~mm}$-sodium/potassium phosphate buffer pH 7.3, 0.25 $\mu \mathrm{mol} \beta$-NADH, $18 \mu \mathrm{g} \mathrm{L}$-malate: $\mathrm{NAD}^{+}$oxidoreductase (EC 1.1.1.37) and $18 \mu \mathrm{g} \mathrm{L}$-aspartate: 2-oxoglutarate aminotransferase (EC 2.6.1.1). After equilibration at $37^{\circ} \mathrm{C}$, the rate of spontaneous $\beta$-NADH oxidation was measured by the fall in absorbance at $340 \mathrm{~nm}$. Then $50 \mu 1$ pronase-digested protein (see kelow) and $2 \mu \mathrm{mol}$ sodium 2-oxoglutarate were added, and the fall in $A_{340}$ was used to measure L-aspartate, using the pure acid as standard.

(ii) Asparagine. When the absorbance had fallen to a constant value in an aspartate assay as above, $16 \mu \mathrm{g}$ asparaginase (EC 3.5.1.1) was added and more $\beta-\mathrm{NADH}$, as necessary. The further fall in $A_{340}$ after mixing was used to assay L-asparagine, using pure L-asparagine as standard.

(iii) Glutamate. An adaptation of the method of Bernt \& Bergmeyer (1963) was used, in which glutamate was converted to 2-oxoglutarate with the concomitant reduction of $\beta$-NAD ${ }^{+}$. The reaction mixture contained (in a final volume of $1 \mathrm{ml}$ ) $10 \mathrm{~mm}$-sodium phosphate buffer $\mathrm{pH} 7.6,12.5 \mu \mathrm{mol} \beta-\mathrm{NAD}^{+}$and 15 units L-glutamate: $\mathrm{NAD}(\mathrm{P})^{+}$oxidoreductase $(\mathrm{EC} 1.4 .1 .3)$. Equilibration was at $37^{\circ} \mathrm{C}$, and the reaction was started by adding 50 to $100 \mu \mathrm{l}$ pronase-digested protein. The increase in $A_{\mathbf{3 4 0}}$ was used as a measure of L-glutamic acid, calibrated against the pure acid. 
(iv) Glutamine. This was first converted to free glutamate by the enzyme glutaminase (EC 3.5.1.2): 0.25 units glutaminase, $25 \mu \mathrm{l}$ protein sample and $5 \mathrm{~mm}$-sodium acetate buffer $\mathrm{pH} 4.9$ (in a final volume of $125 \mu \mathrm{l}$ ) were incubated at $37^{\circ} \mathrm{C}$ for $30 \mathrm{~min}$, and the mixture was then assayed for free glutamate as before (in a final volume of $1 \mathrm{ml}$ ). The free glutamine in the sample was determined by subtraction. Pure L-glutamine was used as a standard.

Pronase digestion of $C$. fusca protein. This was done by the method of Smyth (1967): $1 \mathrm{ml}$ of a solution of protein dissolved in $1 \mathrm{M}-\mathrm{NaOH}$ and neutralized with $\mathrm{H}_{2} \mathrm{SO}_{4}$ was incubated with $1 \mathrm{ml}$ of a $0.5 \mathrm{mg} \mathrm{ml}^{-1}$ solution of type 6 Streptomyces griseus pronase in $0.1 \mathrm{M}$-sodium phosphate buffer $\mathrm{pH} 7.0 \mathrm{for} 24 \mathrm{~h}$, then boiled for $5 \mathrm{~min}$ to denature the pronase, freeze-dried and resuspended in $10 \mathrm{~mm}$-sodium phosphate buffer $\mathrm{pH} 7 \cdot 6$.

Estimation of tryptophan in C. fusca protein. Tryptophan is destroyed during the acid hydrolysis stage of amino acid analysis, and so it was estimated by the method of Sasaki et al. (1975), using 1 mM-L-tryptophan as an internal standard in each determination.

Incorporation of ${ }^{18} \mathrm{O}$ into the proteins of $C$. fusca. Washed cells of $C$. fusca were resuspended at twice the desired cell density in $50 \mathrm{ml}$ of fresh sterile medium in a $100 \mathrm{ml}$ jacketed glass vessel and incubated for $1.5 \mathrm{~h}$ at $25^{\circ} \mathrm{C}$ in the light (this is apparently the time required for recovery from the stress-induced damage caused by centrifugation during harvesting; Märkl, 1976). An equal volume of medium made up in water having 1.66 atom $\%$ excess of ${ }^{18} \mathrm{O}$ (normalized for deuterium) was added. Samples of $20 \mathrm{ml}$ were withdrawn at intervals for extraction and analysis of protein.

Conversion of ${ }^{18} \mathrm{O}$-labelled protein to carbon dioxide. A modification of the method of Unterzaucher (1951, 1952) was used. A pyrolysis gas train/vacuum line similar to that described by Steyermark (1961) was used, and the method is fully described by Richards (1978). A stream of oxygen-free nitrogen was swept over the sample which was heated to $900{ }^{\circ} \mathrm{C}$. The gas stream was carried over a platinized carbon catalyst at $950^{\circ} \mathrm{C}$ which converted all sample oxygen to carbon monoxide. It was then passed over copper turnings at the same temperature to remove sulphur compounds and through a tube containing packed soda-asbestos to remove any acids originating from halogens or sulphur in the sample. Carbon monoxide was then converted to carbon dioxide by passage over pure iodine pentoxide at $120^{\circ} \mathrm{C}$. In this way only one oxygen atom per $\mathrm{CO}_{2}$ molecule came from the original protein sample. Iodine vapour was removed from the gas stream by cooling to $-80^{\circ} \mathrm{C}$ and $\mathrm{CO}_{2}$ was frozen out at $-197^{\circ} \mathrm{C}$. Sample $\left(\mathrm{CO}_{2}\right)$ pressure was measured with a mercury manometer and the gas was collected in a sample bottle cooled in liquid nitrogen.

Analysis for ${ }^{18} \mathrm{O}$ in carbon dioxide. This was done using an A.E.I. MS20 Isotope Ratio mass spectrometer. This has two matched capillary inlets which were used for the sample gas and a standard of pure carbon dioxide containing ${ }^{18} \mathrm{O}$ at atmospheric abundance. A double collector system was used to permit the simultaneous measurement of the mass 44 peak and that at mass 46 (corresponding to a molecule of $\mathrm{CO}_{2}$ containing 1 atom of ${ }^{18} \mathrm{O}$ ). The machine was modified by the inclusion of an auto-valving system to permit the sample and standard gas to be admitted alternately, allowing compensation for drift and machine response. Measured ratios of mass $46 / 44$ peak heights were corrected for the blank (gas collected in the pyrolysis system in the absence of any protein sample, representing $\mathrm{CO}_{2}$ at natural abundance) and converted to atom $\%$ concentrations of ${ }^{18} \mathrm{O}$ in the sample of protein. From the increase in this parameter with time of exposure of the cells to $\mathrm{H}_{2}{ }^{18} \mathrm{O}$ the intracellular protein turnover rate could be derived by expressing the incorporation of ${ }^{18} \mathrm{O}$ as a proportion of the maximum attainable enrichment if all peptide-bond oxygen in protein had become labelled to the same enrichment as the medium (100\% turnover). For this calculation the percentage of protein oxygen which resides in side-chains and in peptide bonds is required. This was calculated from the data on overall protein composition (Table 1), obtained by analysis of hydrolysed bulk protein. Once ${ }^{18} \mathrm{O}$ incorporation had been expressed in this way, the resulting figure was doubled (as described by Borek et al., 1958), since there is only a $50 \%$ probability of an ${ }^{18} \mathrm{O}$ atom in an amino carboxyl group being fixed in a peptide bond on resynthesis of protein from an amino acid previously released by degradation.

Incorporation of tritium from ${ }^{3} \mathrm{H}_{2} \mathrm{O}$ into $\mathrm{C}$. fusca protein. Cells harvested from 21 cultures were washed and resuspended in medium containing ${ }^{3} \mathrm{H}_{2} \mathrm{O}\left(1.5 \mathrm{mCi} \mathrm{ml}^{-1}, 55 \mathrm{MBq} \mathrm{ml}{ }^{-1}\right)$. After 26 to $28 \mathrm{~h}$ growth in this medium, the cells were harvested, washed three times to remove unincorporated label, and resuspended in unlabelled medium to the same density. Samples were withdrawn at intervals, and protein was extracted.

Measurement of $\alpha$-carbon tritium in C. fusca protein. Protein samples extracted from cells labelled with ${ }^{3} \mathrm{H}_{2} \mathrm{O}$ were dissolved in $1 \mathrm{ml} 1 \mathrm{M}-\mathrm{NaOH}$ and centrifuged to remove insoluble matter. Then $4 \mathrm{ml} 0.5 \mathrm{M}-\mathrm{Tris}$ buffer pH. 9.2 was added and the samples were dialysed to remove exchangeable label against three changes of $10 \mathrm{~mm}-\mathrm{NaOH}(1 \mathrm{leach})$ for $2 \mathrm{~h}$ at $37^{\circ} \mathrm{C}$, and twice against 11 distilled water at $37^{\circ} \mathrm{C}$ for $1 \mathrm{~h}$. Samples of dialysed protein were acid-hydrolysed on Dowex ion-exchange resin as described by Humphrey \& Davies (1975). Free amino acids in the column eluate were estimated fluorometrically using fluorescamine \{4-phenylspiro[furan-2(3H),1'-phthalan]-3,3'-dione\} (Udenfriend et al., 1972): $0.1 \mathrm{ml}$ hydrolysate was 

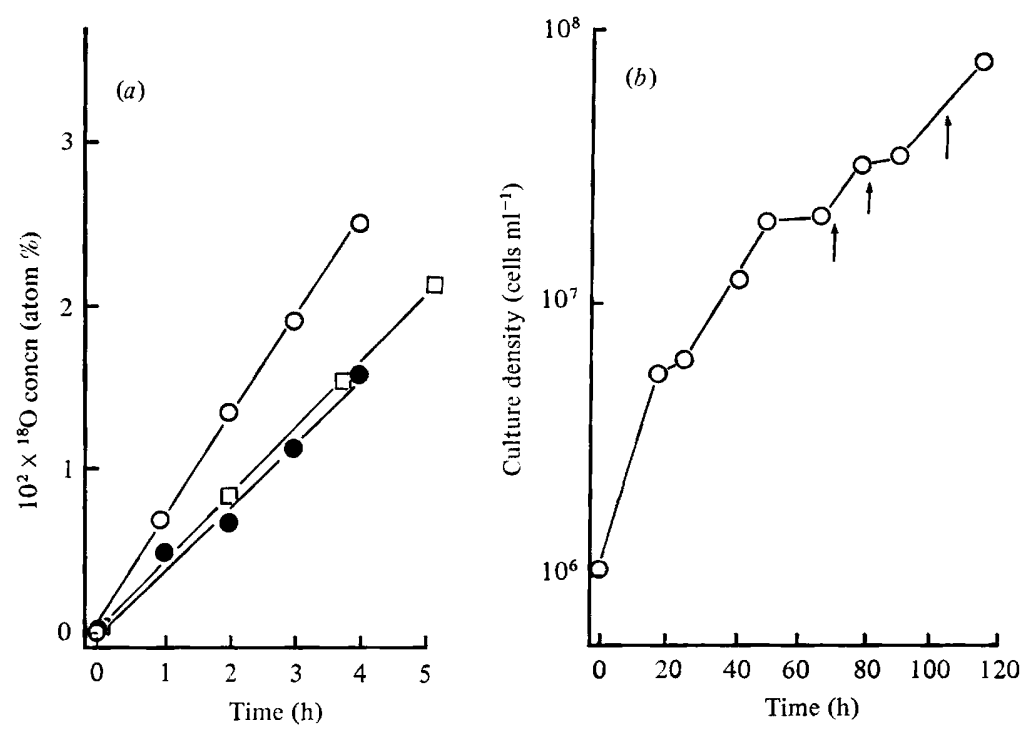

Fig. 1. Incorporation of ${ }^{18} \mathrm{O}$ from enriched medium into the proteins of $C$. fusca. (a) Incorporation from medium at an enrichment of 0.83 atom \% excess, averaged from the results for 'soluble' and 'insoluble' protein fractions, and weighted for their relative abundances: $\bigcirc$, cells taken from an autotrophically growing culture at a density of $2.54 \times 10^{7}$ cells ml ${ }^{-1}$; $O$, cells taken from a culture

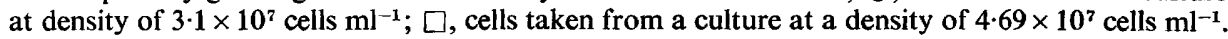
(b) Growth curve of the culture from which cells were withdrawn for incorporation of ${ }^{18} \mathrm{O}$; the points of sampling are indicated by the arrows. The growth rate, averaged over the whole growth curve, was $0.028 \mathrm{~h}^{-1}$.

added to $1.4 \mathrm{ml} 0.2 \mathrm{M}$-sodium borate buffer $\mathrm{pH} 9.0$; then $0.5 \mathrm{ml}$ of a $0.2 \mathrm{mg} \mathrm{ml}^{-1}$ solution of fluorescamine in acetone was added, mixing rapidly, and fluorescence was recorded at 475 to $490 \mathrm{~nm}$ with actinic illumination at $390 \mathrm{~nm}$. The assay was standardized against L-leucine. $\alpha$-Carbon hydrogen was released from amino acids by the acetic anhydride racemization technique described by Humphrey \& Davies (1976). Radioactivity was measured in $1 \mathrm{ml}$ portions of the distillate, using as a background the radioactivity of a sample of pure water carried through the racemization/distillation procedure.

Chemicals. Unless specified in the text, these were obtained from usual laboratory suppliers and were of the highest grade obtainable. Radiochemicals were from The Radiochemical Centre, Amersham. $\mathrm{H}_{2}{ }^{18} \mathrm{O}$ was obtained from Prochem, British Oxygen, London.

\section{RESULTS AND DISCUSSION}

Measurement of ${ }^{18} \mathrm{O}$ incorporation into the proteins of growing C. fusca

Chlorella fusca was grown autotrophically from a small inoculum, and portions were removed at the points indicated by arrows in Fig. $1(b) .{ }^{18} \mathrm{O}$ from $\mathrm{H}_{2}{ }^{18} \mathrm{O}$ at an enrichment of 0.83 atom $\%$ excess was then incorporated. In all cases, ${ }^{18} \mathrm{O}$ appeared in both the 'soluble' and 'insoluble' cell protein fractions. Figure 1(a) shows the rate of incorporation after averaging the 'soluble' and 'insoluble' data in each experiment, and weighting for the relative abundance of the two fractions.

The growth curve of Fig. 1(b) shows that the culture was growing with partial synchrony [index of synchrony for the third division was $0 \cdot 273$ (Bernstein, 1960)]. This was not deliberately induced, but sometimes occurred in cultures grown from small inocula. The three portions removed for ${ }^{18} \mathrm{O}$ incorporation corresponded to points immediately after, before and during cell division. The specific growth rate $(\mu)$ averaged over the whole growth curve was $0.028 \mathrm{~h}^{-1}$. 


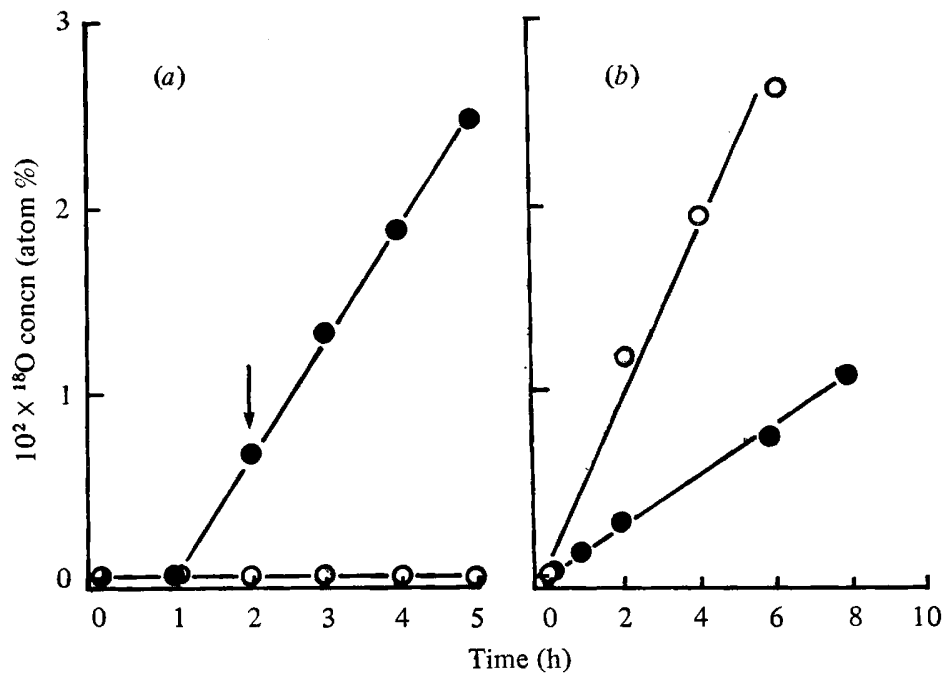

Fig. 2. Incorporation of ${ }^{18} \mathrm{O}$ from enriched medium into the proteins of $C$. fusca. The isotopic enrichment of the medium was $0.83 \%$. (a) Cells were grown autotrophically to a density of $2 \cdot 17 \times 10^{7} \mathrm{ml}^{-1}$ before ${ }^{18} \mathrm{O}$ incorporation in full growth medium: $\bigcirc$, cells in the presence of $2.5 \mu \mathrm{g}$ cycloheximide $\mathrm{ml}^{-1} ; \boldsymbol{O}$, cells in the absence of cycloheximide. The culture in the absence of cycloheximide was diluted twofold at the point arrowed, with medium at the same ${ }^{18} \mathrm{O}$ enrichment. (b) Cells were grown autotrophically and then nitrogen-starved prior to the incorporation of ${ }^{18} \mathrm{O}$ : , cells grown to $2.0 \times 10^{7} \mathrm{ml}^{-1}$ then starved for $1.5 \mathrm{~h}$, $O$, cells grown to $3.28 \times 10^{7} \mathrm{ml}^{-1}$ then starved for $17 \cdot 5 \mathrm{~h}$. All data are averaged from 'soluble' and 'insoluble' values, weighted for the abundance of the two protein fractions.

\section{Effect of cycloheximide on incorporation of ${ }^{18} \mathrm{O}$}

Figure 2(a) shows the result of a similar experiment in which autotrophically grown cells at a density of $2.17 \times 10^{7} \mathrm{ml}^{-1}$ were harvested and resuspended in two portions. Cycloheximide $\left(2.5 \mu \mathrm{g} \mathrm{ml}^{-1}\right)$, which totally inhibits protein synthesis in C. fusca (Morris, 1966), was added to one portion and then both were exposed to $\mathrm{H}_{2}{ }^{18} \mathrm{O}$. There was no detectable incorporation into either protein fraction in the presence of the inhibitor, whilst in its absence incorporation proceeded at a measurable rate.

In order to establish that the twofold dilution of a culture with medium enriched in ${ }^{18} \mathrm{O}$ which took place at the start of an experiment did not significantly interfere with metabolism, a similar dilution was performed in the middle of the incorporation period with cells in the absence of cycloheximide. The enrichment of the diluting medium was corrected so as not to change the overall medium enrichment. The point of dilution is indicated by the arrow in Fig. 2(a); clearly, the rate of ${ }^{18} \mathrm{O}$ incorporation was unchanged.

\section{Incorporation of ${ }^{18} \mathrm{O}$ into the proteins of nitrogen-starved $C$. fusca}

Similar incorporation experiments performed on cells which had been grown autotrophically then harvested, washed twice and resuspended in nitrogen-free medium prior to the addition of (nitrogen-free) ${ }^{18} \mathrm{O}$-enriched medium revealed similar linear incorporation rates (Fig. 2b). Again the data have been averaged from both the 'soluble' and 'insoluble' protein fractions and weighted for their abundances. After $1.5 \mathrm{~h}$ of nitrogen starvation the rate of ${ }^{18} \mathrm{O}$ incorporation observed was $1.46 \times 10^{-3}$ atom $\% \mathrm{~h}^{-1}$. An approximately fourfold higher rate of ${ }^{18} \mathrm{O}$ incorporation was detected when a culture had been nitrogen-starved for $17.5 \mathrm{~h}$ prior to addition of the enriched medium. 


\section{Table 1. Amino acid composition of C. fusca bulk protein}

Samples of 'soluble' and 'insoluble' protein fractions from cells of $C$. fusca were subjected to $18 \mathrm{~h}$ hydrolysis in $6 \mathrm{M}-\mathrm{HCl}$ at $105^{\circ} \mathrm{C}$, and the resulting amino acid mixture was separated on sulphonated polystyrene resin and quantified with ninhydrin. The amino acids tryptophan, asparagine, aspartate, glutamine and glutamate were assayed separately in pronase-digested protein as described in Methods. The amounts of each amino acid are expressed as molar percentages in protein. All values are the means of data from three experiments done on different cultures, have been corrected for degradation of the amino acids during hydrolysis, and are $\pm 5 \%$. Values for Chlorella spp. reported by other authors are shown for comparison.

\begin{tabular}{|c|c|c|c|c|c|c|}
\hline \multirow[b]{3}{*}{ Component } & \multirow{2}{*}{\multicolumn{2}{|c|}{$\begin{array}{l}\text { Autotrophically grown } \\
\text { cells }\end{array}$}} & \multirow{2}{*}{\multicolumn{2}{|c|}{$\begin{array}{l}16 \mathrm{~h} \text { nitrogen-starved } \\
\text { cells }\end{array}$}} & \multicolumn{2}{|c|}{ Published results } \\
\hline & & & & & \multirow[b]{2}{*}{$\begin{array}{c}\text { Fowden } \\
(1951) \\
*+8\end{array}$} & \multirow{2}{*}{$\begin{array}{c}\text { Thinh \& } \\
\text { Griffiths } \\
\text { (1976) } \\
\dagger \ddagger\end{array}$} \\
\hline & $\begin{array}{l}\text { 'Soluble' } \\
\text { protein }\end{array}$ & $\begin{array}{l}\text { 'Insoluble' } \\
\text { protein }\end{array}$ & $\begin{array}{l}\text { 'Soluble' } \\
\text { protein }\end{array}$ & $\begin{array}{l}\text { 'Insoluble' } \\
\text { protein }\end{array}$ & & \\
\hline Aspartate & $3 \cdot 26$ & 3.04 & 3.53 & $2 \cdot 96$ & $8 \cdot 60$ & ) 9.63 \\
\hline Asparagine & $5 \cdot 26$ & $4 \cdot 91$ & $5 \cdot 70$ & $4 \cdot 78$ & & $\int 9 \cdot 63$ \\
\hline Threonine & $5 \cdot 16$ & $5 \cdot 18$ & $6 \cdot 46$ & $5 \cdot 51$ & $3 \cdot 90$ & $5 \cdot 70$ \\
\hline Serine & $6 \cdot 60$ & 6.09 & $7 \cdot 61$ & $7 \cdot 29$ & $4 \cdot 43$ & $5 \cdot 48$ \\
\hline Glutamate & 1.91 & 1.91 & $2 \cdot 08$ & $2 \cdot 08$ & 10.48 & 0.92 \\
\hline Glutamine & $7 \cdot 92$ & $7 \cdot 15$ & $9 \cdot 00$ & $7 \cdot 27$ & $\int 10 \cdot 48$ & \}9.92 \\
\hline Proline & $7 \cdot 07$ & $6 \cdot 61$ & $5 \cdot 73$ & $5 \cdot 80$ & $4 \cdot 84$ & $5 \cdot 56$ \\
\hline Glycine & $8 \cdot 74$ & $9 \cdot 33$ & $9 \cdot 33$ & $11 \cdot 18$ & $8 \cdot 33$ & $10 \cdot 60$ \\
\hline Alanine & $10 \cdot 28$ & 10.09 & $11 \cdot 03$ & $12 \cdot 03$ & $10 \cdot 34$ & 11.96 \\
\hline Cysteine & $3 \cdot 19$ & 2.92 & $3 \cdot 51$ & $2 \cdot 74$ & $0 \cdot 27$ & $0 \cdot 12$ \\
\hline Valine & 6.97 & $7 \cdot 02$ & 6.93 & $6 \cdot 68$ & $7 \cdot 39$ & $7 \cdot 33$ \\
\hline Methionine & $1 \cdot 60$ & $0 \cdot 17$ & $1 \cdot 75$ & 0.78 & $1 \cdot 88$ & 0.83 \\
\hline Isoleucine & $4 \cdot 08$ & $4 \cdot 66$ & $4 \cdot 27$ & $4 \cdot 52$ & $4 \cdot 70$ & $4 \cdot 77$ \\
\hline Leucine & $8 \cdot 53$ & $9 \cdot 75$ & 8.97 & $10 \cdot 60$ & $8 \cdot 19$ & 8.97 \\
\hline Tyrosine & $2 \cdot 56$ & $2 \cdot 59$ & 2.94 & $3 \cdot 11$ & $3 \cdot 76$ & $2 \cdot 41$ \\
\hline Phenylalanine & $3 \cdot 62$ & $5 \cdot 18$ & $4 \cdot 26$ & $5 \cdot 74$ & $3 \cdot 76$ & $4 \cdot 00$ \\
\hline Histidine & $1 \cdot 83$ & $2 \cdot 15$ & 0.41 & 0.33 & $1 \cdot 48$ & $1 \cdot 78$ \\
\hline Tryptophan & $0 \cdot 38$ & $0 \cdot 38$ & $0 \cdot 18$ & $0 \cdot 18$ & 1.41 & ND \\
\hline Lysine & 6.49 & $5 \cdot 38$ & 0.92 & $1 \cdot 19$ & 6.85 & $6 \cdot 28$ \\
\hline Arginine & $4 \cdot 57$ & 5.02 & $5 \cdot 38$ & $5 \cdot 22$ & $5 \cdot 31$ & $4 \cdot 67$ \\
\hline \multicolumn{7}{|l|}{ Side-chain } \\
\hline oxygen $(\%)$ & $27 \cdot 4$ & $26 \cdot 4$ & $30 \cdot 0$ & $27 \cdot 6$ & & \\
\hline
\end{tabular}

ND, Not done.

* Rapidly growing $C$. fusca var. vacuolata $211-8 \mathrm{P}$ protein acid-hydrolysed by $\mathrm{HCl}$ /acetic acid mixture in the presence of $4 \%(\mathrm{w} / \mathrm{v}) \mathrm{SnCl}_{2}$ to prevent humin formation, followed by one-dimensional chromatography in a three-solvent system. The organism is called $C$. vulgaris by Fowden (1951), but has since been renamed (see Trinci \& Thurston, 1976, footnote on p. 57).

$\dagger$ Emerson strain of Chlorella, perchloric acid extracted.

¥ Values given for glutamate refer to the total of glutamate plus glutamine, and similarly for aspartate plus asparagine, since the amide is converted to the free acid during hydrolysis.

$\S$ Total amide nitrogen (glutamine plus asparagine) was measured as $4 \cdot 1 \%$.

\section{Amino acid composition of $C$. fusca protein}

The amino acid composition of the 'soluble' and 'insoluble' fractions of $C$. fusca protein is given in Table 1 for autotrophically grown cells, and for cells which had been nitrogenstarved for $16 \mathrm{~h}$. The values obtained were essentially similar to published data for this strain and for the Emerson strain of Chlorella. The percentage of the protein oxygen which is in side-chains rather than peptide bonds is also shown, as this is required for the estimation of rates of protein turnover from ${ }^{18} \mathrm{O}$ incorporation data. A very similar composition was seen for both protein fractions in both growing and starved cells, except that the contents of lysine and, to a lesser extent, histidine were dramatically reduced by nitrogen starvation. 


\section{Table 2. Protein turnover in C. fusca measured by incorporation of ${ }^{18} \mathrm{O}$ from enriched water into protein}

Cells from cultures of $C$. fusca in either autotrophic growth or under conditions of nitrogen starvation were harvested and resuspended, and ${ }^{18} \mathrm{O}$ was incorporated from $\mathrm{H}_{2}{ }^{18} \mathrm{O}$ in the medium at an enrichment of 0.83 atom $\%$ excess for $5 \mathrm{~h}$. The protein was extracted and analysed for ${ }^{18} \mathrm{O} /{ }^{16} \mathrm{O}$ ratios as described in Methods. Apparent protein turnover rates were calculated on the assumption that ${ }^{18} \mathrm{O}$ is incorporated into protein only via the hydrolysis of peptide bonds. The effect of making alternative assumptions about incorporation via exchange into amino acid sidechains is demonstrated in Tables 3 and 4. All data are averages of values for 'soluble' and 'insoluble' protein fractions weighted for their relative abundances.

\begin{tabular}{|c|c|c|c|}
\hline Growth state & $\begin{array}{c}10^{-7} \times \\
\text { Initial } \\
\text { culture density } \\
\left(\text { cells } \mathrm{ml}^{-1} \text { ) }\right.\end{array}$ & $\begin{array}{l}10^{3} \times \\
\text { Rate of }{ }^{18} \mathrm{O} \\
\text { incorporation } \\
\left(\text { atom } \% \mathrm{~h}^{-1}\right)\end{array}$ & $\begin{array}{c}\text { Apparent } \\
\text { rate of } \\
\text { turnover } \\
\left(\% \mathrm{~h}^{-1}\right)\end{array}$ \\
\hline Growing & $2 \cdot 53$ & $6 \cdot 29$ & $2 \cdot 13$ \\
\hline Growing & $3 \cdot 10$ & $3 \cdot 78$ & $1 \cdot 28$ \\
\hline Growing & $4 \cdot 69$ & $3 \cdot 44$ & $1 \cdot 46$ \\
\hline Nitrogen-starved* & $2 \cdot 00$ & $1 \cdot 46$ & 0.51 \\
\hline Nitrogen-starved & $3 \cdot 28$ & $4 \cdot 57$ & $1 \cdot 77$ \\
\hline
\end{tabular}

* Cells nitrogen-starved for $1.5 \mathrm{~h}$ prior to ${ }^{18} \mathrm{O}$ incorporation.

+ Cells nitrogen-starved for $17 \cdot 5 \mathrm{~h}$ prior to ${ }^{18} \mathrm{O}$ incorporation.

\section{Protein turnover in C. fusca}

Table 2 shows the rate of protein turnover derived from the ${ }^{18} \mathrm{O}$ incorporation rates previously shown, accepting the original assumption (Borek et al., 1958) that the only significant port of entry of ${ }^{18} \mathrm{O}$ into protein is via the hydrolytic cleavage of peptide bonds. This interpretation would indicate a significant rate of protein turnover within growing cells and a substantial decrease in turnover at the onset of nitrogen starvation. However, incorporation of ${ }^{18} \mathrm{O}$ into amino acid side-chains would also contribute to ${ }^{18} \mathrm{O}$ incorporation into protein. This would, in turn, result in the values for protein turnover being overestimates when calculated as above.

\section{Extent of side-chain exchange with $\mathrm{H}_{2}{ }^{18} \mathrm{O}$ in $\mathrm{C}$. fusca}

Autotrophically grown $C$. fusca at $1.25 \times 10^{7}$ cells $\mathrm{ml}^{-1}$ were washed and resuspended at $5.5 \times 10^{6}$ cells ml-1 in $200 \mathrm{ml}$ of fresh medium and $3.5 \mu \mathrm{mol}$ of either $\mathrm{L}-\left[{ }^{14} \mathrm{C}\right]$ glutamine or $\mathrm{L}-\left[{ }^{14} \mathrm{C}\right]$ asparagine containing $20 \mu \mathrm{Ci}(740 \mathrm{kBq})$ was added. At intervals up to $2 \mathrm{~h}$ after addition of the label, $35 \mathrm{ml}$ samples were withdrawn, washed, and the free amino acid pool of each was extracted as described by Richards \& Thurston (1980). Samples were run on the autoanalyser and portions of the eluate were analysed for radioactivity. Figure $3(a)$ shows the rate of entry of radioactivity supplied as glutamine into various amino acids, and Fig. $3(b)$ shows the result expressed as the proportion of total incorporated label remaining as glutamine, and similarly for asparagine. This clearly suggests that there is a rapid equilibrium between glutamate and glutamine, which favours the free acid $(91 \%)$, and a similar one between aspartate and asparagine, which favours the amide $(85 \%)$. These equilibria represent an exchange in which ${ }^{18} \mathrm{O}$ from water can be fixed into amino acid side-chains. The overall size of the pools of these acids remained constant during the experiment and protein synthesis occurred at the usual rate; thus, the data may be taken as representative of the situation during an ${ }^{18} \mathrm{O}$ incorporation experiment. Thus, some ${ }^{18} \mathrm{O}$ incorporation must be a consequence of side-chain exchange. In the absence of precise data for the rate of exchange of side-chain oxygen for all of the oxygen-containing groups in amino acids, a range of possible combinations of exchanges have been used to calculate the effect of side-chain incorporation on total ${ }^{18} \mathrm{O}$ incorporation for growing (Table 3) and nitrogen-starved (Table 4) cultures. 

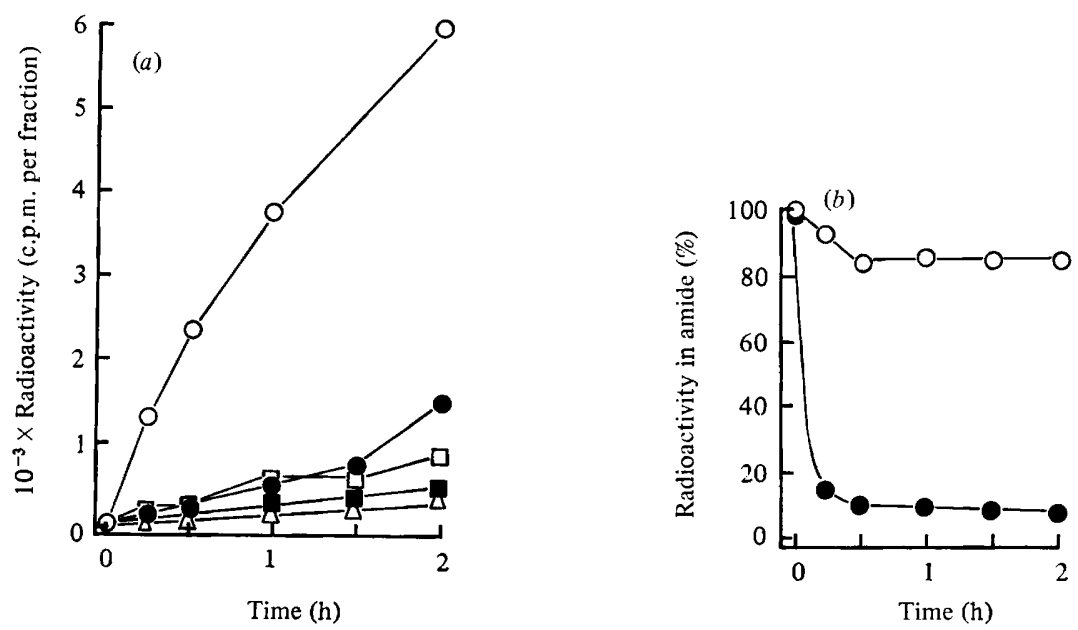

Fig. 3. Side-chain exchange between glutamate and glutamine, and aspartate and asparagine, in amino acid pools of $C$. fusca. ( $a$ ) Rate of entry of radioactivity into various amino acids by exchange from L-glutamine. An autotrophically grown culture at $1.25 \times 10^{7}$ cells $\mathrm{ml}^{-1}$ was resuspended at $5.5 \times 10^{6}$ cells $\mathrm{ml}^{-1}$ and labelled with $3.5 \mu \mathrm{mol}(20 \mu \mathrm{Ci}, 740 \mathrm{kBq})\left[{ }^{14} \mathrm{C}\right]$ glutamine. During exposure to glutamine, radio radioactivity was measured in the pool glutamic acid $(O)$, in the pool proline $(O)$, the glutamine $(\square)$, aspartic acid $(\triangle)$ and material not adsorked to the autoanalyser resin column (a). (b) The proportion of the intracellular pool label which remained as the amide when cells were exposed to $3 \cdot 5 \mu \mathrm{mol}(20 \mu \mathrm{Ci}, 740 \mathrm{kBq}) \mathrm{L}-\left[{ }^{14} \mathrm{C}\right]$ glutamine $(O)$ or L- $\left[{ }^{14} \mathrm{C}\right]$ asparagine $(O)$.

It can be seen that side-chain exchange is more significant in growing than starving cells and that it reduces the apparent rate of turnover. For growing cells, the amount of exchange to be expected on assumptions $c, d$ and $e$ (see Table 3 ) is more than the incorporation actually observed. Thus, as some side-chain exchange clearly occurs relatively rapidly in terms of the time-course of the ${ }^{18} \mathrm{O}$ incorporation experiments (Figs 3 and 4), it is impossible to deduce from these data whether or not protein degradation occurs in growing cells. The data do, however, indicate that overall protein degradation is not more than about $1.5 \% \mathrm{~h}^{-1}$ (Table 3 ). In nitrogen-starved cells the effect of varying the proportion of total ${ }^{18} \mathrm{O}$ incorporation which is assigned to side-chain incorporation is much smaller. At the onset of starvation, turnover was 0.4 to $0.5 \% \mathrm{~h}^{-1}$ and after $17.5 \mathrm{~h}$ starvation was about threefold greater (Table 4).

\section{Measurement of protein turnover in growing C. fusca by ${ }^{3} \mathrm{H}_{2} \mathrm{O}$ labelling}

Autotrophically grown $C$. fusca was labelled with ${ }^{3} \mathrm{H}_{2} \mathrm{O}\left(1.5 \mathrm{mCi} \mathrm{ml}^{-1}, 55 \mathrm{MBq} \mathrm{ml}^{-1}\right)$ for $28 \mathrm{~h}$ while growing at $\mu=0.033 \mathrm{~h}^{-1}$, and resuspended after washing in unlabelled growth medium. Growth continued at the same rate (as judged by cell counts) during the subsequent $100 \mathrm{~h}$. Figure 4 shows the variation in the specific activity of tritium labelling in the $\alpha$-carbon position of peptide amino acid residues with time after resuspension. The activity was measured after dialysis of exchangeable label, and acetic anhydride racemization to selectively remove the $\alpha$-carbon tritium, and the data have been corrected for the dilution of radioactivity due to new protein synthesis resulting from growth in the unlabelled medium. This increase in protein in the culture is also shown in Fig. 4. There is no turnover detectable, but instead an apparent continuing incorporation of tritium into protein at the $\alpha$-carbon position of amino acid residues.

\section{Measurement of protein turnover in nitrogen-starved C. fusca by ${ }^{3} \mathrm{H}_{2} \mathrm{O}$ labelling}

Autotrophically grown $C$. fusca was exposed to ${ }^{3} \mathrm{H}_{2} \mathrm{O}\left(1.5 \mathrm{mCi} \mathrm{ml}^{-1}, 55 \mathrm{MBq} \mathrm{ml}^{-1}\right)$ for $26.5 \mathrm{~h}$, washed and resuspended in unlabelled, nitrogen-free medium. The specific activity 


\section{Table 3. Influence of ${ }^{18} \mathrm{O}$ incorporation into amino acid side-chains on the apparent rate of protein turnover in growing $C$. fusca cultures}

The amount of ${ }^{18} \mathrm{O}$ incorporation into protein which would be expected to occur in cells growing at $\mu=0.028 \mathrm{~h}^{-1}$ in a medium enriched with 0.83 atom $\%$ excess of $\mathrm{H}_{2}{ }^{18} \mathrm{O}$, from the protein amino acid composition data in Table 1, was calculated on the basis of five possible assumptions regarding exchange between oxygen in amino acid side-chains with that in the medium, such as the glutamate/glutamine equilibrium, and assuming no entry via the hydrolytic cleavage of peptide bonds. For three measured rates of ${ }^{18} \mathrm{O}$ incorporation in cells growing at this rate, the effect of subtracting this source of labelling on the resultant calculated rate of protein turnover is shown.

Expt 1

Observed incorporation

$10^{3} \times \quad \begin{gathered}\text { Observed incorporation } \\ =6.29 \times 10^{-3} \text { atom } \% \mathrm{~h}^{-1}\end{gathered}$
Calculated

Assump- incorporation

tion

about

exchange

(see

footnotes)
$10^{3} \times$

Incorporation

side-chain

exchange

(atom \%

$\mathrm{h}^{-1}$ )

\section{0}

$1 \cdot 89$

$5 \cdot 67$

$4 \cdot 80$

$8 \cdot 58$ due to

turnover

(atom \%

$\mathrm{h}^{-1}$ )

6.29
4.40
0.62
1.49
$<0$

Expt 2

Observed incorporation $=3.78 \times 10^{-3}$ atom $\% \mathbf{h}^{-1}$

$\begin{array}{cc}\begin{array}{c}10^{3} \times \\ \begin{array}{c}\text { Incorporation } \\ \text { due to } \\ \text { turnover } \\ (\text { atom } \% \\ \left.\mathrm{h}^{-1}\right)\end{array}\end{array} & \begin{array}{c}\text { Rate of } \\ \text { turnover } \\ \left(\% \mathbf{h}^{-1}\right)\end{array} \\ 3.78 & 1.28 \\ 1.89 & 0.64 \\ <0 & <0 \\ <0 & <0 \\ <0 & <0\end{array}$

Expt 3

Observed incorporation $=3.44 \times 10^{-3}$ atom $\% \mathrm{~h}^{-1}$

\begin{tabular}{|c|c|}
\hline $\begin{array}{l}10^{3} \times \\
\text { Incorporation } \\
\text { due to } \\
\text { turnover } \\
(\text { atom } \% \\
\left.\text { h }^{-1}\right)\end{array}$ & $\begin{array}{l}\text { Rate of } \\
\text { turnover } \\
\left(\% \mathrm{~h}^{-1}\right)\end{array}$ \\
\hline 3.44 & 1.46 \\
\hline 1.55 & 0.66 \\
\hline$<0$ & $<0$ \\
\hline$<0$ & $<0$ \\
\hline$<0$ & $<0$ \\
\hline
\end{tabular}

$a$ : No exchange of ${ }^{18} \mathrm{O}$ in medium with any sidemchain peptide oxygen. Entry of ${ }^{18} \mathrm{O}$ strictly by hydrolytic cleavage of peptide bonds.

$b$ : One side-chain carboxyl oxygen of glutamate and aspartate in the free pool becomes instantly labelled (by acid/amide exchange) to the enrichment of the medium, and this is incorporated into protein by synthesis.

$c$ : Similar to $b$ except all side-chain oxygen atoms in glutamate and aspartate and glutamine and asparagine become labelled.

$d$ : One side-chain oxygen in glutamate and aspartate, and also the hydroxyl oxygen of threonine, serine and tyrosine, become instantly labelled to the enrichment of the medium.

$e:$ All side-chain oxygen in glutamate, aspartate, glutamine and asparagine, and the side-chain hydroxyl groups of threonine, serine and tyrosine, become labelled by exchange.

of $\alpha$-carbon hydrogen in peptide residues of protein was measured at intervals during the next $250 \mathrm{~h}$. The data were corrected for the net loss of protein occurring during the first $100 \mathrm{~h}$, after which the total protein became more or less constant. Two exponential rates of protein turnover can be seen in Fig. 5. For about the first $70 \mathrm{~h}$ protein was degraded at $3.47 \% \mathrm{~h}^{-1}$ (half-life $20 \mathrm{~h}$ ), followed by degradation at $1.11 \% \mathrm{~h}^{-1}$ (half-life $63 \mathrm{~h}$ ) which continued for the duration of the experiment.

Radioactivity lost from protein could all be accounted for in the culture fluid during the incubation in unlabelled medium. Computer fitting of the data to an equation of the form $y=k_{1} \mathrm{e}^{-k_{2} t}+k_{3} \mathrm{e}^{-k_{4} t}$ where $t$ is time, $y$ is amount of label, $k_{1}$ and $k_{3}$ are the amounts, and $k_{2}$ and $k_{4}$ are the decay rates of the two stability classes detected, yielded figures of $85 \%$ and $15 \%$ of total protein having turnover rates of 3.47 and $1.11 \% \mathrm{~h}^{-1}$, respectively. The change in degradation rate may equally have been due to an overall reduction in metabolic activity after such a prolonged period of nitrogen starvation, rather than to the relatively faster removal of radioactivity from proteins with higher rates of degradation.

\section{Reliability of data obtained using ${ }^{3} \mathrm{H}_{2} \mathrm{O}$ exchange with water}

Humphrey \& Davies (1975) devised this method to minimize underestimation of rates of protein degradation resulting from amino acid recycling (Davies \& Humphrey, 1978). The results presented here reveal two disturbing properties of the method. First, during growth, C. fusca cultures show a continuing increase in corrected specific activity of the $\alpha$-carbon 


\section{Table 4. Influence of ${ }^{18} \mathrm{O}$ incorporation into amino acid side-chains on the apparent rate of protein turnover in nitrogen-starved $C$. fusca cultures}

Two measurements were made on the rate of ${ }^{18} \mathrm{O}$ incorporation from medium enriched with 0.83 atom $\%$ excess of $\mathrm{H}_{2}{ }^{18} \mathrm{O}$ into the protein of nitrogen-starved $C$. fusca cultures, one of which was starved for $1.5 \mathrm{~h}$ prior to the incorporation (initial cell density $2 \times 10^{7} \mathrm{ml}^{-1}$ ), the other for $17.5 \mathrm{~h}$ prior to incorporation (initial cell density $3.28 \times 10^{7} \mathrm{ml}^{-1}$ ). The results in this table show the effect on the calculated rate of protein turnover of correcting for the incorporation of ${ }^{18} \mathrm{O}$ not by the hydrolytic cleavage of peptide bonds, but by exchange between medium oxygen and that in amino acid side-chains on the basis of different assumptions regarding the extent of such exchanges, and using the formula:

True incorporation (due to
protein turnover) assuming
a given exchange and the data on protein composition in Table 1.

\begin{tabular}{|c|c|c|c|c|c|c|}
\hline \multirow[b]{2}{*}{$\begin{array}{l}\text { Assumption } \\
\text { about } \\
\text { exchange } \\
\text { (see footnotes } \\
\text { to Table 3) }\end{array}$} & \multicolumn{3}{|c|}{$\begin{array}{l}\text { Expt } 1: \text { Cells starved for } 1.5 \mathrm{~h} \\
\text { Observed incorporation } \\
=1.46 \times 10^{-3} \text { atom } \% \mathrm{~h}^{-1}\end{array}$} & \multicolumn{3}{|c|}{$\begin{array}{l}\text { Expt 2: Cells starved for } 17.5 \mathrm{~h} \\
\text { Observed incorporation } \\
=4.57 \times 10^{-3} \text { atom } \% \mathrm{~h}^{-1}\end{array}$} \\
\hline & $\begin{array}{c}10^{3} \times \\
\text { Calculated } \\
\text { side-chain } \\
\text { incorporation } \\
\left(\text { atom } \% \mathbf{h}^{-1}\right)\end{array}$ & $\begin{array}{c}10^{3} \times \\
\text { Incorporation } \\
\text { due to } \\
\text { turnover } \\
\left(\text { atom } \% \mathrm{~h}^{-1}\right)\end{array}$ & $\begin{array}{l}\text { Rate of } \\
\text { turnover } \\
\left(\% \mathrm{~h}^{-1}\right)\end{array}$ & $\begin{array}{c}10^{3} \times \\
\text { Calculated } \\
\text { side-chain } \\
\text { incorporation } \\
\left(\text { atom } \% \mathbf{h}^{-1}\right)\end{array}$ & $\begin{array}{c}10^{3} \times \\
\text { Incorporation } \\
\text { due to } \\
\text { turnover } \\
\left(\text { atom } \% \mathbf{h}^{-1}\right)\end{array}$ & $\begin{array}{l}\text { Rate of } \\
\text { turnover } \\
\left(\% \mathrm{~h}^{-1}\right)\end{array}$ \\
\hline$a$ & 0 & 1.46 & 0.511 & 0 & $4 \cdot 57$ & 1.77 \\
\hline$b$ & 0.06 & $1 \cdot 40$ & 0.49 & $0 \cdot 21$ & $4 \cdot 36$ & 1.69 \\
\hline$c$ & $0 \cdot 18$ & $1 \cdot 28$ & 0.45 & 0.58 & 3.99 & 1.54 \\
\hline$d$ & $0 \cdot 17$ & $1 \cdot 29$ & 0.45 & 0.58 & 3.99 & 1.54 \\
\hline$e$ & 0.27 & $1 \cdot 19$ & 0.42 & 0.89 & 3.68 & 1.42 \\
\hline
\end{tabular}

hydrogen (tritium) of amino acid residues of protein long after cells have been washed and transferred to unlabelled medium. This indicates either that some amino acids were in pools which did not readily exchange tritium back into water (but which would be incorporated into protein) or that some tritium incorporated into other positions in amino acid residues could be rearranged to the $\alpha$-carbon position. Secondly, the apparent degradation rate of C. fusca protein during nitrogen starvation was more than $3 \% \mathrm{~h}^{-1}$ for at least $80 \%$ of total protein as measured using the ${ }^{3} \mathrm{H}_{2} \mathrm{O}$ exchange method. This value is at least double the value (or rather range of values) obtained using ${ }^{18} \mathrm{O}$ exchange. It is not obvious why the ${ }^{18} \mathrm{O}$ exchange procedure should underestimate protein degradation. The measurements were made in cultures where protein concentration was constant for the first $24 \mathrm{~h}$ of nitrogen starvation (Richards, 1978) and so the overall rate of protein synthesis was the same as the overall rate of degradation, both equalling the measured rate of amino acid flux. After incorporation of ${ }^{3} \mathrm{H}_{2} \mathrm{O}$ there was a large decrease in protein concentration in the culture (Fig. 5) which suggests, together with the high value obtained for overall rate of protein degradation, that the $C$. fusca cells were physiologically perturbed. We suggest that the very large amounts of radioactivity which are required for the ${ }^{3} \mathrm{H}_{2} \mathrm{O}$ exchange procedure lead to significant radiation damage which in turn may lead to elevated rates of protein degradation. This view is supported by the data of Chandorkar et al. (1978) who observed profound physiological perturbation in Chlorella pyrenoidosa cultures with relatively small amounts $\left(2.5\right.$ to $10 \mu \mathrm{Ci} \mathrm{ml}^{-1}, 95$ to $\left.370 \mathrm{kBq} \mathrm{ml}^{-1}\right)$ of the very much more energetic isotope ${ }^{32} \mathrm{P}$. The alternative explanation, that the rate of ${ }^{18} \mathrm{O}$ incorporation was unrepresentatively low as a consequence of a kinetic isotope effect, is unlikely as the mass difference is small (only $12.5 \%$ of the mass of the lighter isotope). 


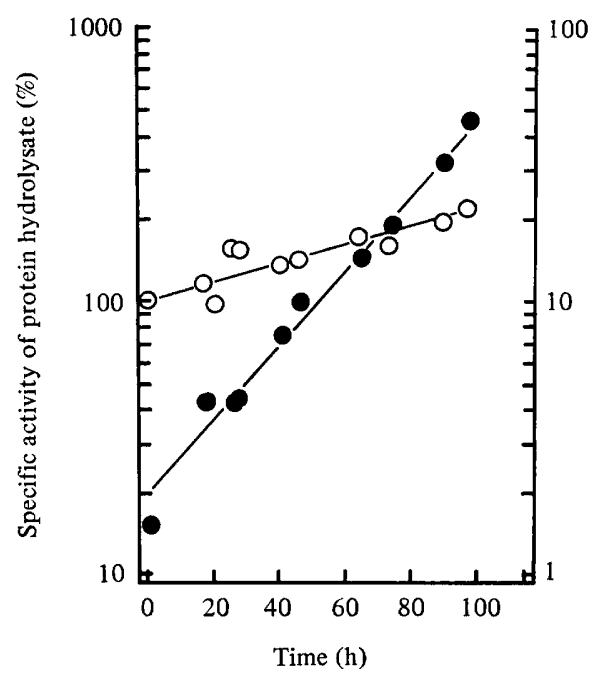

Fig. 4

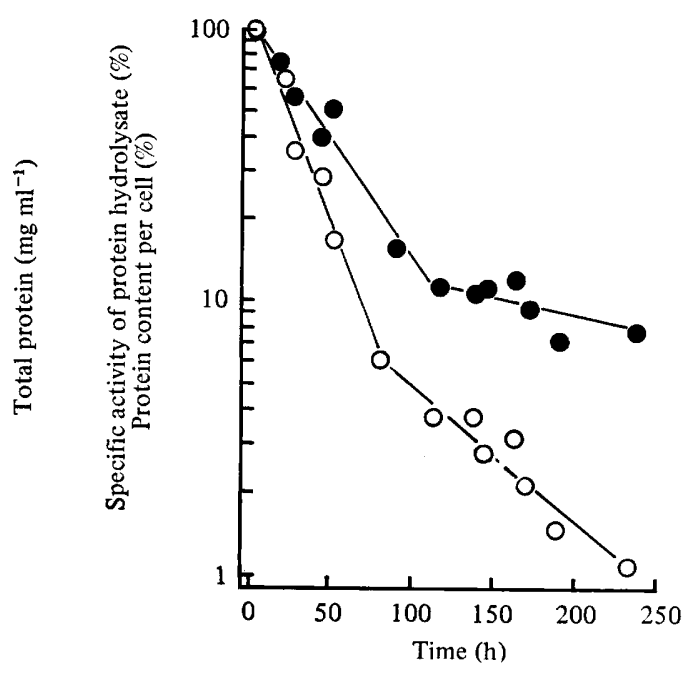

Fig. 5

Fig. 4. Chlorella fusca grown autotrophically to a cell density of $7 \cdot 08 \times 10^{5} \mathrm{ml}^{-1}$ was labelled for $28 \mathrm{~h}$ with ${ }^{3} \mathrm{H}_{2} \mathrm{O}$ at a specific activity of $1.5 \mathrm{mCi} \mathrm{ml}^{-1}\left(55 \mathrm{MBq} \mathrm{ml}^{-1}\right)$ during which time the growth rate was $0.033 \mathrm{~h}^{-1}$. The change in specific activity $(O)$ of $\alpha$-carbon hydrogen in 'soluble' protein amino acid residues during the subsequent growth of the washed culture on unlabelled medium is shown. Growth on the unlabelled medium was at $0.033 \mathrm{~h}^{-1}$ (measured by cell numbers), and the results have been normalized for the increase in total protein due to growth on this medium. Total protein is shown (O). Exchangeable label was removed by alkaline dialysis, and the $\alpha$-carbon was released selectively by acetic anhydride racemization. Results are average values from duplicate samples processed independently.

Fig. 5. Chlorella fusca at a cell density of $4.47 \times 10^{6} \mathrm{ml}^{-1}$ was labelled for $26 \cdot 5 \mathrm{~h}$ with ${ }^{3} \mathrm{H}_{2} \mathrm{O}$ at a specific activity of $1.5 \mathrm{mCi} \mathrm{ml}^{-1}\left(55 \mathrm{MBq} \mathrm{ml}^{-1}\right)$, and then washed and resuspended in nitrogen-free medium. The change in the specific activity $(O)$ of $\alpha$-carbon hydrogen in 'soluble' protein amino acid residues is shown (corrected for the net loss of protein). The protein content per cell is also shown (O). Exchangeable label was removed by alkaline dialysis, and the $\alpha$-carbon was selectively released by acetic anhydride racemization. Results are average values from duplicate samples processed independently.

\section{The magnitude of protein degradation in growing and starved C. fusca}

The results show clearly that protein degradation occurs in nitrogen-starved C. fusca, but the overall rate of degradation remains uncertain within the range between 0.5 to $1.5 \% \mathrm{~h}^{-1}$ and $3.5 \% \mathrm{~h}^{-1}$ depending on the method used (Table 4 and Fig. 5).

The results for growing cells presented in this paper show that the overall rate of protein degradation was not more than $2.1 \% \mathrm{~h}^{-1}$ but were not sufficiently precise to preclude the possibility that protein degradation was negligible under these conditions. The detection of protein degradation in growing $C$. fusca cultures by an alternative procedure is described in the following paper (Thurston \& Richards, 1980).

We are very grateful to Professor D. D. Davies and Dr T. J. Humphrey for advice and discussion concerning their experimental procedure. We thank Dr R. G. Price and Sally Taylor, Biochemistry Department, Queen Elizabeth College, for their assistance with and use of the automated amino acid analyser. Analysis of ${ }^{18} \mathrm{O}$ incorporation into protein was carried out in the Isotope Unit, Queen Elizabeth College, and we thank Dr G. Ayrey for the use of his equipment and for his help and advice. L.R. thanks the Science Research Council for a studentship. 


\section{REFERENCES}

BERNLOHR, R. W. (1972), ${ }^{18} \mathrm{O}$ probes of protein turnover, amino acid transport, and protein synthesis in Bacillus licheniformis. Journal of Biological Chemistry 247, 4893-4899.

Bernstein, E. (1960). Synchronous division in Chlamydomonas moewusii. Science 131, 15281529.

BernT, E. \& Bergmeyer, H.-U. (1963). In Methods of Enzymatic Analysis, pp. 384-391. Edited by H.-U. Bergmeyer. New York: Academic Press.

Borek, E., Ponticorvo, D. \& RITtenberG, D. (1958). Protein turnover in microorganisms. Proceedings of the National Academy of Sciences of the United States of America 44, 369-374.

Chandorkar, K. R., Szachrajuk, R. B. \& Clark, G. M. (1978). Effect of extremely low radiation dosages on synchronised cultures of Chlorella pyrenoidosa. Health Physics 34, 495-499.

Davies, D. D. \& Humphrey, T. J. (1978). Amino acid recycling in relation to protein turnover. Plant Physiology 61, 54-58.

Donald, A. S. R. (1973). The products of pronase digestion of purified blood group specific glycoproteins. Biochimica et biophysica acta 317, 420 436.

Fensom, A. H. \& Pirt, S. J. (1975). Protein turnover measured by ${ }^{18} \mathrm{O}$ exchange with $\mathrm{H}_{2}{ }^{18} \mathrm{O}$ in nongrowing cells of Agrobacterium tumefaciens. Journal of General Microbiology 87, 159-162.

FowDEN, L. (1951). The composition of the bulk protein of Chlorella. Biochemical Journal 50, 355358.

Goldberg, A. L. \& Dice, J. F. (1974). Intracellular protein degradation in mammalian and bacterial cells. Annual Review of Biochemistry 43, 835-869.

Goldberg, A. L. \& St John, A. C. (1976). Intracellular protein degradation in mammalian and bacterial cells, Part II. Annual Review of Biochemistry 45, 747-803.

Halvorson, H. O. (1958). Studies on protein and nucleic acid turnover in growing cultures of yeast. Biochimica et biophysica acta 27, 267-276.

Humphrey, T. J. \& Davies, D. D. (1975). A new method for the measurement of protein turnover. Biochemical Journal 148, 119-127.

Humphrey, T. J. \& Davies, D. D. (1976). A sensitive method for the measurement of protein turnover based on the measurement of $2{ }^{3} \mathrm{H}$-amino acids in protein. Biochemical Journal 156, 561-568.

MaNDElstaM, J. (1960). The intracellular turnover of protein and nucleic acids, and its role in biochemical differentiation. Bacteriological Reviews 24, 289-308.

MÄrKL, H. (1976). Hydrodynamic stress capacity of microorganisms (experiments with algae). $A b$ stracts of the 5th International Fermentation Symposium, p. 79. Edited by H. Dellweg. Berlin: Westkreuz-Druckerei und Verlag.
MORRIS, J. (1966). Inhibition of protein synthesis by cycloheximide (actidione) in Chlorella. Nature, London 211, 1190-1192.

Pfleiderer, G. (1963). In Methods of Enzymatic Analysis, pp. 381-383. H.-U. Bergmeyer. New York: Academic Press.

RichARDS, L. (1978). Measurement of intracellular protein turnover in the green alga Chlorella. Ph.D. thesis, University of London.

Richards, L. \& Thurston, C. F. (1980). Uptake of leucine and tyrosine and their intracellular pools in Chlorella fusca var. vacuolata. Journal of General Microbiology 121, 39-47.

Roberts, R. B., Cowie, D. B., Abelson, P. H., Bolton, E. T. \& Britten, R. J. (1955). In Studies of Biosynthesis in Escherichia coli. Publications of the Carnegie Institution of Washington 607, 13-20.

Sasaki, T., Abrams, B. \& Horecker, B. L. (1975). A fluorometric method for the determination of the tryptophan content of proteins. Analytical Biochemistry 65, 396-404.

SмyтH, D. G. (1967). Techniques in enzymic hydrolysis. Methods in Enzymology 11, 214-231.

SteYermark, A. (1961). Microdetermination of oxygen. In Quantitative Organic Microanalysis, 2nd edn, pp. 377-409. Edited by A. Steyermark. New York: Academic Press.

Thinh, L. V. \& Griffiths, D. J. (1976). Amino acid composition of autotrophic and heterotrophic cultures of the Emerson strain of Chlorella. Plant and Cell Physiology 17, 193-196.

Thurston, C. F. \& Richards, L. (1980). Protein turnover in Chlorella fusca var. vacuolata: detection of a rapidly degraded class of protein in growing and non-growing cells. Journal of General Microbiology 121, 63-68.

Trinci, A. P. J. \& Thurston, C. F. (1976). Transition to the non-growing state in eukaryotic microorganisms. Symposia of the Society for General Microbiology 26, 58-80.

Udenfriend, S., Stein, S., Bohlen, P., Dairman, W., Leimgruber, W. \& Weigele, M. (1972). Fluorescamine: a reagent for assay of amino acids, peptides, proteins and primary amines in the picomole range. Science 178, 871-872.

UNTERZAUCHER, J. (1951). Elementary determination of oxygen. A method of determining carbon and hydrogen developed from it, and a new procedure for carrying out the Dumas nitrogen determination for compounds difficult to burn. Mikrochemie vereinigt mit Mikrochemica acta 36/37, 706-726.

UNTERZAUCHER, J. (1952). The direct microdetermination of oxygen in organic substances. Analyst 77, 584-595. 